\title{
Laparoscopic ureterocalicostomy in pigs - experimental study
}

\author{
Ureterocalicostomia laparoscópica em suínos - estudo experimental
}

\author{
Paulo Fernando de Oliveira Caldas ${ }^{\mathrm{I}}$ Luiz Carlos de Almeida Rocha ${ }^{\mathrm{I}}$ Marília Teresa de Oliveira ${ }^{\mathrm{II}}$ \\ Michelli Westphal de Ataíde ${ }^{\mathrm{III}}$ Julio David Spagnolo ${ }^{\text {IV }}$ João Pedro Scussel FerantiI \\ Fernando Wiecheteck de Souza ${ }^{I I}$ Marco Augusto Machado Silva ${ }^{\text {III }}$ Maurício Veloso Brun ${ }^{\text {II* }}$
}

\begin{abstract}
This study aimed to evaluated laparoscopic ureterocalicostomy as treatment of experimental ureteropelvic junction (UPJ) obstruction in pigs. Ten male Large White pigs weighting approximately $28.4( \pm 1.43) \mathrm{kg}$ were used in the current study. The UPJ obstruction was created laparoscopically by double-clipping of the left ureter. After 14 days the animals underwent laparoscopic ureterocalicostomy $f$ The animals were sacrificed for subsequent retrograde pyelography in order to assess the anastomotic patency on the $28^{\text {th }}$ day. The laparoscopic procedure for experimental obstruction of UPJ was successfully performed in all animals, as well as the laparoscopic ureterocalicostomy. There was intestinal iatrogenic injury in one animal. Satisfactory UPJ patency was noted in $75 \%$ of the animals. There was no stenosis of the proximal anastomosis between the ureter and the lower pole of the kidney in $37.5 \%$, mild stenosis in $37.5 \%$ and severe stenosis in $25 \%$ of the animals. The laparoscopic approach for reestablishment he urinary flow by ureterocalicostomy was feasible in the porcine model. The ascending pyelography revealed satisfactory results of the laparoscopic ureterocalicostomy.
\end{abstract}

Key words: laparoscopy, urinary, constriction, nephrology, swine model.

RESUMO

$O$ estudo teve como objetivo avaliar a ureterocalicostomia laparoscópica no tratamento de obstrução da junção ureteropiélica (JUP) em modelo experimental suíno. Foram selecionados 10 suínos machos da raça Large White com

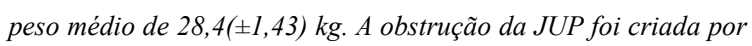
técnica laparoscópica transperitoneal, com aplicação de dois clipes de titânio no ureter esquerdo. Passados 14 dias, os animais foram submetidos à ureterocalicostomia laparoscópica. No $28^{\circ}$ dia após a ureterocalicostomia, foram sacrificados para a remoção dos rins e posterior pielografia retrógrada para avaliação da permeabilidade anastomótica. A obstrução da JUP foi obtida com sucesso em todos os animais, assim como a ureterocalicostomia laparoscópica, apesar de ter havido lesão intestinal em um dos animais. Boa permeabilidade foi observada em $75 \%$ dos casos, posteriormente à anastomose entre o ureter proximal e o cálice maior caudal do rim, onde $37,5 \%$ dos animais não apresentaram estenose, 37,5\% apresentaram estenose leve, enquanto $25 \%$ apresentaram estenose severa. Foi possivel restabelecer o fluxo urinário por ureterocalicostomia laparoscópica e os resultados anatômicos obtidos por meio das pielografias ascendentes foram considerados satisfatórios.

Palavras-chave: laparoscopia, urinário, estenose, nefrologia, modelo suíno.

\section{INTRODUCTION}

From the early 90's to the present, several advances in minimally invasive urologic surgery were achieved. Since the first laparoscopic nephrectomy, which was performed in 1991 (CLAYMAN et al., 1991), several institutions have been employing

IDepartamento de Urologia, Faculdade de Medicina, Universidade Federal do Paraná (UFPR), Curitiba, PR, Brasil.

IIDepartamento de Clínica de Pequenos Animais (DCPA), Faculdade de Medicina Veterinária, Centro de Ciências Rurais (CCR), Universidade Federal de Santa Maria (UFSM), Av. Roraima, 1000, Cidade Universitária, Bairro Camobi, 97105-900, Santa Maria, RS, Brasil. E-mail: mauriciovelosobrun@hotmail.com. "Corresponding author.

IIIDepartamento de Cirurgia de Pequenos Animais, Faculdade de Agronomia e Medicina Veterinária, Universidade de Passo Fundo (UPF), Passo Fundo, RS, Brasil.

${ }^{\mathrm{IV}}$ Departamento de Cirurgia de Grandes Animais, Faculdade de Medicina Veterinária, Universidade de São Paulo (USP), São Paulo, SP, Brasil. 
the laparoscopic approach in renal surgeries. Subsequently, several refined reconstructive techniques such as the laparoscopic pyeloplasty for obstruction of the ureteropelvic junction (UPJ) have been developed (JARRETT et al., 2002).

Laparoscopic procedures present the same functional results as the conventional open techniques, besides better cosmetic results, less requirement for analgesics, shorter hospital stays and convalescence time, as well as quick return to labor activities (SEAGER et al., 1990; WAGH et al., 2006).

In some patients submitted to laparoscopic pyeloplasty, the renal pelvis may present surgically inaccessible at the surgery time. In such cases, the surgeon may consider conversion to the open approach for pyeloplasty or ureterocalicostomy, which has not been widely performed laparoscopically. Ureterocalicostomy is indicated in case of failure of a previous ureteropyeloplasty, substantial deposition of fibrosis on the UPJ and marked impairment of tissue handling, stenosis of a large segment of proximal ureter and consequent impossibility of achieving a tension-free anastomosis, presence of intrarenal pelvis and other abnormalities. In some peculiar cases such as severe hydronephrosis, ureterocalicostomy can provide functional drainage of the collector system with resumption of the symptoms and preservation of the renal function (CHERULLO et al., 2003).

The repair of UPJ total obstruction is an important life-threatening condition that requires more studies. The advantages of the laparoscopic approach over the open techniques were well described. However, laparoscopic pyeloplasty is not always possible to be carried out. In such cases, ureterocalicostomy is indicated. Therefore, this study aimed to evaluated laparoscopic ureterocalicostomy as treatment of experimental ureteropelvic junction (UPJ) obstruction in pigs. Moreover, the anastomotic line was assessed for leakage with ascending pyelography.

\section{MATERIAL AND METHODS}

Ten male Large-White swines weighting $28.4( \pm 1.43) \mathrm{kg}$ were assessed. The animals were kept in adequate pigsties and received daily balanced nutrition and water ad libitum. On the day before surgery, the swines were submitted to preoperative clinical evaluation. Food and water were held 12 and 6 hours before surgery, respectively. Before entering the operative room, the animals were hygienized using water and soap and the abdominal surgical area was properly shaved.
The same anesthetic protocol was adopted for all animals in all surgical procedures. The premedication was achieved using a mixture of morphine sulfate $\left(0.3 \mathrm{mg} \mathrm{kg}^{-1}\right)$, midazolam $(0.1 \mathrm{mg}$ $\left.\mathrm{kg}^{-1}\right)$ and acepromazine $\left(0.1 \mathrm{mg} \mathrm{kg}^{-1}\right)$ intramuscularly. General anesthesia was induced following 20 minutes using sodium thiopental (10mg kg-1, IV) and maintained using halothane vaporized in $100 \%$ oxygen, in semi-closed circuit and assisted ventilation regimen. The animals received sodium ampicillin (20mg kg-1 IV) 30 minutes before surgery and fluid therapy with normal saline $\left(2 \mathrm{ml} \mathrm{kg}^{-1} \mathrm{~h}^{-1}\right)$ through an ear marginal venal access.

The swines were positioned in right lateral recumbency, in order to approach the left ureter. The antisepsis of the surgical field was accomplished using polyvinylpyrrolydone-iodine (PVP-I), followed by surgical draping. The first step consisted of the creation of the stenosis, using the laparoscopic approach. A 10$\mathrm{mm}$ trocar was inserted through the lateral margin of the of the left rectus abdominis muscle, using the open technique. Thereafter, $\mathrm{CO}_{2}$ pneumoperitoneum was created under $2 \mathrm{~L} \mathrm{~min}{ }^{-1}$ flow rate and maximum intraabdominal pressure of $12 \mathrm{mmHg}$. The second $10-\mathrm{mm}$ trocar was introduced under laparoscopic guidance for the right hand and a third 5-mm trocar was positioned for the left hand instruments. The principles of port triangulation were followed.

The peritoneum was dissected at the level of the caudal pole of the kidney. The ureter was identified and dissected adjacently to the renal artery for complete occlusion by double ligation with titanium clips, as close as possible to the UPJ. Finally, the pneumoperitoneum was drained and the muscular layer was closed using nylon 2.0 USP in simple interrupted pattern.

On the postoperative period, the animals received flunixin meglumine (1.1 $\mathrm{mg} \mathrm{kg}^{-1}$, i.m.) for three days, $0.5 \mathrm{mg} \mathrm{kg}^{-1}$ of morphine sulfate in 6-hour interval during the first two days and $0.3 \mathrm{mg}$ $\mathrm{kg}^{-1}$ in the following three days. A topic silver sulfadiazine $0.1 \%$ associated with cipermetrin $0.4 \%$ was sprayed on the surgical wounds twice a day, for seven days.

Following 14 days of the creation of UPJ total obstruction, the animals were subjected to laparoscopic ureterocalicostomy. A new 3-port laparoscopy was performed avoiding the scars of the first procedure. The same port triangulation technique was used.

For the reconstructive approach, the following steps were accomplished: section of the renal caudal pole; aspiration of urine for bacterial 
culture assays; opening of the ureter; insertion of an ureteral catheter, and uretero-calicial anastomosis. In the first step, a fibrosis was identified in the renal hilum, which was induced following laparoscopic creation of the UPJ total obstruction. Afterwards, the renal caudal pole was identified and the ureter was dissected from the obstruction site to the level of the iliac vessels.

The peritoneum of the renal caudal pole was opened and the area of renal resection was delimited using a Maryland forceps and monopolar diathermy. Subsequently, the renal parenchyma was sectioned, avoiding opening the major calices. The parts of the resected renal caudal pole were retrieved through the $10-\mathrm{mm}$ trocar using a laparoscopic reducer. The urine was aspirated through a renal puncture at the level of the major calyx in order to perform bacterial culture assays. In the next step, the major calyx was opened and the remaining urine was aspirated. The ureter was partially opened immediately caudal to the obstruction. A forth puncture was then established using a 5-mm trocar at the level of the axillary line for the insertion of a 6-fr. ureteral catheter. A Mixter forceps was placed through the major calyx inside the collector system through the renal parenchyma. The catheter was then directed to the ureter, so that the posterior extremity was placed within the bladder and its terminal openings remained within the urinary collector system.

Following the placement of the catheter, the terminal end of the transected ureter was enlarged using a small longitudinal incision. For the anastomosis, a 5-0 USP polyglactin 910 thread was used in a simple interrupted pattern. The first stitch was placed on the inferior angle of the ureter and on the lateral edge of the major calix. Thereafter, the subsequent stitches were applied on the posterior aspect of the anastomosis. Finally, the suture of the anterior aspect of the ureter was performed. By the end of the suturing, the catheter was attached to the peritoneum with a simple interrupted suture in order to avoid migration of its terminal openings. The exteriorized part of the catheter was attached to the subcutaneous tissue at the level of the forth port incision using nylon monofilament 2-0 thread.

The pneumoperitoneum was completely drained. The trocars were withdrawn from the abdominal wall under laparoscopic guidance. The muscular layers, aponeurosis and the skin were sutured using nylon monofilament 2-0 thread, in a simple interrupted pattern. At the end of the surgery, the animals remained in the recovery room and the same procedures previously adopted for postoperative care were accomplished.
On the $14^{\text {th }}$ postoperative day, the urinary catheters were withdrawn from all animals following neuroleptoanalgesia using a mixture of morphine $\left(0.3 \mathrm{mg} \mathrm{kg}^{-1}\right)$ and midazolam $\left(0.1 \mathrm{mg} \mathrm{kg}^{-1}\right)$ intramuscularly.

On the $28^{\text {th }}$ day post laparoscopic ureterocalicostomy, the swines were subjected to euthanasia for resection of the kidneys and ureters and ascending pyelography. The animals were premedicated and anesthetized in the same fashion as for the previous procedure, followed by sacrifice using $40 \mathrm{ml}$ of potassium chloride $10 \%$ intravenously.

For ascending pyelography, the kidneys were filled with a diatrizoante meglumine contrast through a 6-fr. ureteral catheter. Care was taken in order to avoid contrast leakage. Radiographs were performed during the ureteral filling phase for assessment the permeability and integrity of the anastomosis. The stenosis was scored after the ascending pyelography, which was ranked as: 1 no visible stenosis; 2 - mild stenosis; 3 - moderate stenosis; 4 - total obstruction, according to the contrast flux in the anastomotic site. The results were considered good/positive if stenosis was absent or mild, and ineffective/negative if stenosis was moderate or if total obstruction was present.

\section{RESULTS}

The experimental induction of UPJ total obstruction was successfully accomplished and resulted in no major trans and postoperative complications in all animals. Mean surgical time was of $21.2( \pm 3.33)$ minutes. There was no relevant bleeding during all surgeries. Mean surgical time for repair of the UPJ total obstruction (i.e., from skin incision to the last suture) was of 138.9 $( \pm 45.28)$ minutes. Mean time for anastomosis was $60.3( \pm 29.33)$ minutes. The number of stitches necessary to complete the anastomosis ranged from 6 to 8 . It Was diagnosed macroscopically fibrosis at the level of the renal hilum in all cases, as well as hydronephrosis. There was iatrogenic injury of the bowel in one swine, though without intestinal leakage (swine 7). The perforation was sutured laparoscopically using a polyglactin 910 5-0 USP thread, in a simple interrupted pattern.

Bleeding was also negligible in all surgeries during laparoscopic ureterocalicostomy. Bacterial growth assessment was negative in all urine samples. The ascending pyelography examination was successfully carried out in 8 out of 10 animals. Two swines died in the early 
postoperative period. In both cases, the causa mortis was not determined.

Regarding the results of the ascending pyelography, good permeability was observed in $75 \%$ of the cases following anastomosis between the proximal ureter and the major calix. Three animals $(37.5 \%)$ did not present stenosis (Figure 1A), three $(37.5 \%)$ presented mild stenosis (Figure 1B), and two (25\%) presented severe stenosis (Figure 1C).

\section{DISCUSSION}

The use of swines in the current study was based on their marked physiological similarities of the urinary tract to the human specie (COURT et al., 2003). The swine specie has been used in a wide range of experimental surgeries. The results of such researches have been closely associated to the development of new surgical techniques and other benefits for adoption in human patients (BAYESGENIS et al., 2000).

The placement of two titanium clips on the left proximal ureter for simulation of UPJ stenosis was technically easy and fast. The clips surrounded the full diameter of the ureter and there was no risk of partial obstruction. No partial obstruction or ligation failure was noted.

By the surgical creation of UPJ obstruction, 14 days were elapsed until laparoscopic repair was carried out. Such time is supposed to be long enough to cause hydronephrosis (CHERULLO et al., 2003). Based on that fact, no image scanning was adopted to confirm the presence of hydronephrosis. Moreover, all swines presented hydronephrosis at the moment of the surgical repair.

No technical difficulty was noted for the creation of UPJ obstruction. All procedures were performed in a short time. The overall surgical time

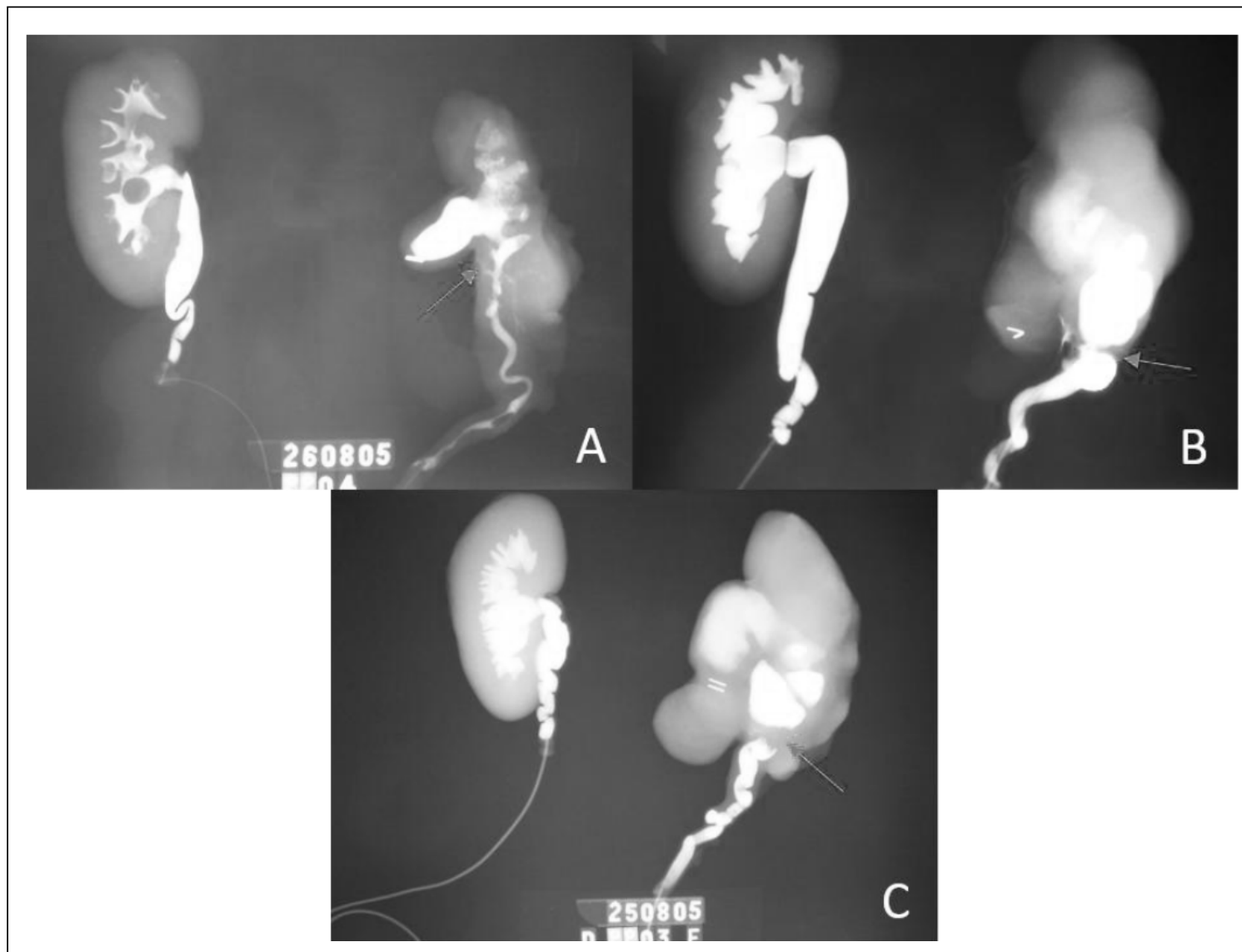

Figure 1 - Images of pyelographies post-mortem performed in Large White pigs underwent to laparoscopic ureterocalicostomies. (A) Pyelography showing the left kidney (LK) subjected to laparoscopic ureterocalicostomy; observe the absence of obstruction at the anastomosis site (arrow). (B) Pyelography showing the right kidney (RK) submitted to ureterocalicostomy, revealing mild obstruction (arrow) at the anastomosis site. (C) Pyelography showing the left kidney (LK) submitted to ureterocalicostomy, revealing severe obstruction (arrow) at the anastomosis site. 
has progressively decreased from the first procedure (28.2 minutes) to the last one (16.8 minutes). Such fact highlights the need for reaching the specific learning for a new technique, even for experienced surgeons as evidenced in the current study.

Regarding the procedure of laparoscopic repair, several important technical aspects deserve to be highlighted. It was possible to preserve of the ureteral vessels during dissection, which were close and adhered to the psoas muscle in some animals. Furthermore, the bleeding following resection of the caudal pole of the kidney was adequately controlled using electrocoagulation and no additional sutures were required.

The use of a ureteral catheter fixed externally at the perineal area of the swine was described (CHERULLO et al., 2003). In the authors' view, such technique was associated to accidental withdrawn of the catheter before the desired moment. Therefore, it was opted for the use of an inner fixation of the ureteral catheter with the outer extremity buried in the subcutaneous space in the current study. Such technique was not previously described for the surgical procedure purposed.

The positioning of the fenestrations of the ureteral catheter was somehow laborious, once it was not easily advanced sometimes, especially nearby the iliac vessels and the ureterovesical junction. Such difficulty was overcome by gently handling the ureter at the sites of difficult advancement. The precise position of the distal extremity of the catheter was confirmed using a laparoscopic forceps, which allowed for the tactile perception of the catheter within the bladder. On the other hand, the positioning of the orifice of the catheter at the anastomosis site was confirmed under direct laparoscopic view.

There were some cases of laceration of the collector system during the accomplishment of some sutures at the uretero-calicial anastomosis site. The collector system was friable in those cases, requiring extra sutures. Care was taken not to include the renal parenchyma at the suture bite, in order to avoid parenchymal retraction and consequent stenosis.

A series of trials involving open ureterocalicostomy presented rates of success ranging from $71 \%$ (ROSS et al., 1990) to $100 \%$ (MATLAGA et al., 2005). In a retrospective study (HAWTHORNE et al., 1997), the rate of success was $72 \%$ out of 50 patients operated on for open ureterocalicostomy. In such context, the data obtained in the current study were closely similar to the results found in those studies involving human patients, as there was good anastomotic permeability in $75 \%$ of the animals operated on. Such fact highlights the usefulness of the experimental model used in the current study for achievement of proficiency prior to the use of laparoscopic ureterocalicostomy in the routine clinical setting. The most frequent complications following ureterocalicostomies are recurrent obstructions and anastomotic failure (SELLI et al., 1992). Similarly, $25 \%$ of the animals presented severe stenosis in the current study.

Few studies revealed data regarding surgical time, duration of hospital stays and estimate blood loss. In a retrospective study, a series of 11 patients subjected to open ureterocalicostomy were assessed (MATLAGA et al., 2005). The mean surgical time was of 292.2 minutes, duration of hospitalization was approximately of 5.1 days and estimate blood loss was of $372.5 \mathrm{ml}$. Concerning the mean surgical time obtained in the current study (138.9 \pm 45.28 minutes), though considering some basic differences of the surgical techniques between swine and human patients, it is truly believe that the laparoscopic technique could result in the accomplishment of ureterocalicostomy in a lower surgical time in comparison to the open technique, as long as the learning curve is reached.

Surgical time for creation of the stenosis (21.2 \pm 3.33 minutes) and for ureterocalicostomy (138.9 \pm 45.28 minutes) were closely similar from those obtained in the first study of the laparoscopic technique of ureterocalicostomy (23.1 and 165.3 minutes, respectively) (CHERULLO et al., 2003). Such fact highlights that laparoscopic ureterocalicostomy in the swine specie is a reproducible procedure that can be employed for the surgical training previously to application in human patients.

An experimental trial employing the swine specie as a model (VANLANGENDONCK et al., 2005), 16 animals were distributed into 4 groups, according to different methods of uretero-calicial anastomosis. The best results $(75 \%$ of success rate) were obtained in the group were suture with polyglactin 910 3-0 and nickel-titanium clips were performed for the anastomosis. Based on those results, suture with polyglactin 910 was chosen for anastomosis in the current study.

Concerning few case reports on laparoscopic ureterocalicostomy, two human patients were successfully treated and presented improvement of the scintilographic pattern following two months (GILL et al., 2004). Another case which reported success on treatment of hydronephrosis by laparoscopic ureterocalicostomy was published (TERAI et al., 2004). The urographic assessment 
revealed marked reduction of hydronephrosis and permeability of the proximal ureter two years following the surgical repair.

Therefore, the authors truly believe that laparoscopic ureterocalicostomy can be safely employed with similar effectiveness seen in the open approach. Laparoscopic ureterocalicostomy might be potentially advantageous in those patients presenting recurrent UPJ obstruction that is difficultly approached or in the presence of long stenosis tract. In such cases, the conventional open approach can be hazardous and life-threatening.

\section{CONCLUSION}

In conclusion, laparoscopic ureterocalicostomy was feasible and allowed the reestablishment of the urinary flow. Moreover, ascending pyelography confirmed that laparoscopic ureterocalicostomy might be effective, although it is considered as a highly complex surgical procedure, which requires extensive training.

\section{ETHICS COMMITTEE AND BIOSECURITY}

This study has been approved by the Ethics Committee (CoEP) of the Universidade de Passo Fundo (UPF) (protocol number 298/2004).

\section{REFERENCES}

BAYES-GENIS, A. et al. Restenosis and hyperplasia: animal models. Currently Intervention Cardiology Reproduction, v.2, p.303-308, 2000. Available from: <http://www.ncbi.nlm.nih.gov/ pubmed/11096680>. Accessed: Ago. 29, 2011.

CHERULLO, E.E. et al. Laparoscopic ureterocalicostomy: a feasibility study. Journal of Urology, v.169, p.23602364, 2003. Available from: <http:/www.ncbi.nlm.nih.gov/ pubmed/12771798>. Accessed: Sept. 16, 2011. doi: 10.1097/01. ju.0000058214.99086.37.

CLAYMAN, R.V. et al. Laparoscopic nephrectomy: initial case report. Journal of Urology, v.146, p.278-282, 1991. Available from: <http://www.ncbi.nlm.nih.gov/pubmed/1830346>. Accessed: Oct. 17, 2011
COURT, F.G. et al. Segmental nature of the porcine liver and potential as a model for experimental partial hepatectomy. Brazilian Journal Surgery, v.90, 440-444, 2003. Available from: <http:// www.ncbi.nlm.nih.gov/pubmed/12673745>. Accessed: Ago. 28, 2011. doi: 10.1002/bjs.4053.

GILL, I.S. et al. Laparoscopic ureterocalicostomy: initial experience. Journal of Urology, v.171, p.1227-1230, 2004. Available from: <http://www.ncbi.nlm.nih.gov/pubmed/14767308>. Accessed: Oct. 17, 2011. doi: 10.1097/01.ju.0000114233.66534.b0.

HAWTHORNE, N.J. et al. Ureterocalicostomy: an alternative to nephrectomy. Journal of Urology, v.115, p.583-586, 1997. Available from: $<$ http://www.ncbi.nlm.nih.gov/pubmed/1271555>. Accessed: Oct. 17, 2011.

JARRETT, T.W. et al. Laparoscopic pyeloplasty: the first 100 cases. Journal of Urology, v.167, p.1253-1256, 2002. Available from: < http://www.ncbi.nlm.nih.gov/pubmed/11832708>. Accessed: Oct. 07, 2011. doi: 10.1016/S0022-5347(05)65276-7.

MATLAGA, B.R. et al. Ureterocalicostomy: a contemporary experience. Urology, v.65, p.42-44, 2005. Available from: <http:// www.ncbi.nlm.nih.gov/pubmed/15667860>. Accessed: Ago. 29, 2011. doi: 10.1016/j.urology.2004.08.024.

ROSS, J.H. et al. Ureterocalicostomy for reconstruction of complicated pelviureteric junction obstruction. Brazilian Journal Urology, v.65, p.322-325, 1990. Available from: <http://www. ncbi.nlm.nih.gov/pubmed/2340366>. Accessed: sept. 16, 2011

SEAGER, S.W.J. Reproductive laparoscopy. Veterinary Clinical North America Small Animal Practice, v.20, p.1369-1375, 1990.

SELLI, C. et al. Experience with ureterocalyceal anastomosis Urology, v.20, p.7-12, 1982. Available from: <http://www.ncbi. nlm.nih.gov/pubmed/7112801>. Accessed: Ago. 16, 2011.

TERAI, A. et al. Retroperitoneoscopic ureterocalicostomy for congenital proximal ureteral stenosis. Urology, v.63, p.982-984, 2004. Available from: <http://www.ncbi.nlm.nih.gov/pubmed/15135003>. Accessed: Ago. 17, 2011. doi: 10.1016/j.urology.2004.01.025.

VANLANGENDONCK, R. et al. Laparoscopic uretrocalicostomy: development of a technique simplified by application of Nitinol clips and a wet monopolar electrosurgery device. Journal of Endourology, v.19, p.225-229, 2005.

WAGH, M.S. et al. Survival studies after endoscopic transgastric ophorectomy and tubectomy in a porcine model. World Journal of Gastrointestinal Endoscopic, v.63, p.473-478, 2006. Available from: <http://www.ncbi.nlm.nih.gov/pubmed/16500399>. Accessed: Ago. 17, 2011. doi: 10.1016/j.gie.2005.06.045. 